Ekspansi: Jurnal Ekonomi, Keuangan, Perbankan dan Akuntansi

ISSN (Online): 2580-7668 ISSN (Print): 2085-5230

Vol. 11, No. 1 (Mei 2019), Hal. 35 - 54

\title{
APLIKASI MODEL SOCIAL COGNITIVE CAREER THEORY UNTUK MEMPREDIKSI NIAT MAHASISWA BEKERJA SEBAGAI AKUNTAN PUBLIK
}

\author{
Vania Pradipta Gunawan ${ }^{1}$, Retno Yuliati ${ }^{2}$ \\ 1,2 Universitas Prasetiya Mulya, Jakarta, Indonesia \\ Email Korespondensi: vania.gunawan@pmbs.ac.id
}

\begin{abstract}
The purpose of this research is to examine the social cognitive career theory (SCCT) model (Lent, Brown, Eु Hackett, 1994) which is composed of self efficacy and outcome expectation to predict university students' intention to work as public accountant. To our best knowledge, this is the first research to examine SCCT model in accounting field; which is done before and after the respondents take auditing course in university. This research used survey method and questionnaire as its instrument. Data from 234 respondents before and 215 respondents after taking auditing course from three universities in Jabodetabek area were taken and analysed using Structural Equation Modeling (SEM). It can be inferred that: (a) the correlation between self-efficacy and university students' intention to be public accountant is stronger after taking auditing course; (b) the correlation outcome expectation and intention to work as public accountant is not significant both prior to and after taking auditing course;(c) the correlation between self-efficacy and outcome expectation is significant only on respondents after taking auditing course. The limitations in this research are the data was taken prior to and after taking Auditing 1 course (prior to taking Auditing 2) and all respondents are from renowned university in major cities. The result of this research is expected to increase the effectiveness of auditing courses to develop university students' competence and confidence to achieve their career as public accountant.
\end{abstract}

Keywords: Social Cognitive Career Theory, Self-Efficacy, Outcome Expectation, Public Accountant Career.

Abstrak: Penelitian ini bertujuan untuk menguji model social cognitive career theory (SCCT) (Lent, Brown \& Hacket, 1994) yang terdiri dari self-efficacy dan outcome expectation untuk memprediksi niat mahasiswa bekerja sebagai akuntan publik. Penelitian ini merupakan penelitan yang pertama kali menguji model SCCT pada ranah akuntansi pada sebelum dan setelah responden mengambil matakuliah auditing. Penelitian ini menggunakan metode survey dengan kuesioner sebagai instrumen penelitian. Dengan menggunakan 234 responden pada sebelum dan 215 responden pada setelah mata kuliah auditing dari 3 universitas di Jabodetabek, penelitian ini dianalisis dengan Structural Equation Modeling (SEM). Hasil menunjukkan bahwa: (a) hubungan antara self-efficacy dan niat mahasiswa untuk menjadi akuntan publik lebih kuat setelah mengambil matakuliah auditing; (b) hubungan antara outcome expectation dan niat untuk bekerja sebagai akuntan publik tidak signifikan baik sebelum dan setelah matakuliah auditing; (c) hubungan antara self-efficacy dan outcome expectation signifikan hanya pada setelah matakuliah auditing. Keterbatasan dalam penelitian ini adalah data diambil sebelum dan setelah matakuliah Auditing 1 (sebelum mengambil matakuliah Auditing 2) dan semua responden berasal dari universitas ternama di kota besar. Hasil dari penelitian ini diharapkan dapat meningkatkan keefektifan matakuliah auditing untuk meningkatkan kompetensi dan kepercayaan diri mahasiswa untuk mewujudkan karir sebagai akuntan publik.

Kata Kunci: Social Cognitive Career Theory, Self-Efficacy, Outcome Expectation, Karir Akuntan Publik.

DOI: $10.35313 /$ ekspansi.v11i1.1203

Riwayat Artikel:

Diterima: $6-11-2018$

Direvisi: $26-2-2019$

Disetujui: $1-3-2019$ 


\section{PENDAHULUAN}

Berdasarkan data dari Ikatan Akuntan Indonesia (IAI) tahun 2015, hanya 25.000 orang yang tercatat sebagai akuntan profesional di Indonesia. Pusat Pembinaan Profesi Keuangan Kementrian Keuangan (PPPK) juga mencatat hanya 1.100 akuntan publik di tahun 2015 dan sebanyak 1.186 akuntan publik di tahun 2016. Hal ini menunjukkan bahwa pertumbuhan profesi ini sangat lambat. Padahal, menurut catatan World Bank (2014), Perguruan Tinggi di Indonesia menghasilkan kurang lebih 35.000 lulusan akuntansi setiap tahunnya. Hal ini mengindikasikan bahwa pertumbuhan jumlah lulusan akuntansi tidak berbanding lurus dengan jumlah pertumbuhan profesi akuntan publik. Padahal kebutuhan akan akuntan publik terus meningkat mengingat peraturan OJK No. 29 tahun 2006 tentang laporan tahunan perusahaan publik yang harus diaudit oleh auditor independen atau akuntan publik.

Beberapa penelitian menunjukkan bukti menurunnya minat mahasiswa pada profesi akuntan publik (Pratama, 2017; Yuliansyah \& Suryani, 2015). Penelitian yang dilakukan oleh Pratama (2017) pada 264 mahasiswa akuntansi di Kota Bandung menunjukkan kesenjangan dalam pilihan karir mahasiswa. Sebagian besar responden $(40,91 \%)$ memilih untuk bekerja sebagai akuntan manajemen daripada sebagai akuntan publik (36,74\%). Begitu pula dengan penelitian yang dilakukan oleh Yuliansyah \& Suryani (2015) yang menemukan bahwa dari 540 mahasiswa akuntansi di Lampung, hanya 1,5\% saja yang tertarik pada profesi akuntan publik. Yuliansyah dan Suryani (2015) menemukan bahwa mahasiswa enggan mengambil jalur karir sebagai akuntan publik disebabkan oleh beberapa alasan, di antaranya adalah minimnya pengetahuan mahasiswa terhadap pekerjaan sebagai akuntan publik, rendahnya kompetensi mahasiswa sebagai auditor, dan persepsi diri sendiri bahwa mereka tidak memenuhi kualifikasi untuk bekerja sebagai akuntan publik.

Persepsi atas rendahnya kompetensi dan tidak dapat memenuhi kualifikasi untuk bekerja sebagai akuntan publik menunjukkan rendahnya self-efficacy yang mahasiswa miliki. Self-efficacy diartikan sebagai tingkat keyakinan seseorang terhadap kemampuan dirinya untuk melakukan pekerjaan yang dapat menghasilkan tujuan tertentu (Bandura, 1986). Tingkat self-efficacy seorang individu atau batas kemampuan individu tersebut dalam melakukan suatu pekerjaan akan mempengaruhi keputusan apakah individu tersebut akan melakukan pekerjaan tersebut atau tidak (Hackett \& Betz, 1981). Penelitian terdahulu membuktikan bahwa self-efficacy berhubungan positif dengan keputusan mahasiswa untuk mewujudkan karir akuntansinya (Ahmad, Ismail, \& Anantharaman, 2015; Hayes \& Credle, 2008; James \& Hill, 2009).

Selain self-efficacy, niat seseorang untuk mewujudkan karirnya dipengaruhi juga oleh outcome expectation (Lent et al., 2001, 1994). Outcome expectation didefinsisikan sebagai keyakinan akan hasil yang akan didapatkan atas aktivitas tertentu (Lent, Brown, \& Hackett, 1994), karena seseorang akan cenderung mengembangkan minatnya pada suatu aktivitas jika mereka percaya pada hasil yang akan mereka dapatkan. Hal ini tentunya menjadi tantangan tersendiri bagi penyedia pendidikan akuntansi di Indonesia untuk menyiapkan lulusan akuntansi dengan kompetensi dan kepercayaan 
diri yang mumpuni, karena tingkat self-efficacy dan outcome expectationdapat berpengaruh terhadap niat dan pilihan karir mahasiswa.

Bremser, Brenner, \& Dascher (1977) mengemukakan bahwa sejak tahun 1950-an, persiapan karir profesional akuntansi sudah menjadi fokus dalam pendidikan akuntansi. Begitu pula pada tahun 1990-an, mahasiswa diperkenalkan kepada kompetensi yang dibutuhkan untuk menjadi akuntan profesional, sehingga pendidikan akuntansi seharusnya sudah didesain untuk menjembatani dunia pendidikan dan profesi akuntansi. Masa studi di perguruan tinggi adalah masa-masa pertama bagi sebagian besar mahasiswa untuk mereka menentukan pilihan karirnya (Erkut \& Mokros, 1984). Ghani, Said, \& Nasir (2008) menemukan bahwa mahasiswa diperkenalkan kepada pilihan karir mereka di bangku perkuliahan oleh para profesional. Senada dengan penelitian tersebut, DeZoort, Lord, \& Cargile (1997) dalam penelitiannya di lima universitas negeri di Amerika Serikat mendapati bahwa respondennya mengetahui banyak mengenai dunia pekerjaan di bangku kuliah. Jadi, saat yang tepat bagi para penyedia pendidikan akuntansi untuk mencetak mahasiswa yang berprospek menjadi akuntan publik selama mahasiswa berada di bangku kuliah.

Membekali mahasiswa akuntansi dengan pengetahuan dan kompetensi sebagai akuntan publik salah satunya adalah melalui matakuliah auditing. Rendahnya minat mahasiswa meniti karir sebagai akuntan profesional menimbulkan pertanyaan apakah matakuliah auditing melakukan perannya untuk membekali mahasiswa dengan skill set yang diperlukan oleh seorang akuntan publik. Dalam matakuliah auditing, mahasiswa diberikan pengetahuan mengenai profesi akuntan publik. Mata kuliah tersebut diharapkan dapat menjadikan mahasiswa paham akan profesi akuntan publik, baik tentang kegiatan yang dilakukan di profesi tersebut, hasil yang mungkin didapat jika menjadi akuntan publik, maupun mengenai skill set yang dibutuhkan untuk menjadi seorang akuntan publik. Intervensi berupa pendidikan diharapkan dapat meningkatkan self-efficacy (Wilson, Kickul, \& Marlino, 2007) dan merubah pandangan mereka tentang outcome expectation mahasiswa yang nantinya akan meningkatkan keinginan untuk mewujudkan karirnya (Diegelman \& Subich, 2001).

Dalam penelitian ini, akan digunakan model yang diadaptasi dari Social Cognitive Career Theory (SCCT) untuk menjelaskan bagaimana pengaruh self-efficacy mahasiswa dan outcome expectation terhadap niat untuk bekerja sebagai akuntan publik (Lent et al., 1994). Penelitian terdahulu telah membuktikan kemapanan model SCCT dalam mewujudkan karir atau pemilihan jurusan pada ranah psikologi (Diegelman $\&$ Subich, 2001), ilmu komputer (Lent, Ezeofor, Morrison, Penn, \& Ireland, 2016), matematika dan ilmu alam (Lent et al., 2001; Navarro, Flores, \& Worthington, 2007), engineering (Lent et al., 2003), sport and leisure (Cunningham, Bruening, Sartore, Sagas, \& Fink, 2005), dan akuntansi (Hayes \& Credle, 2008; James \& Hill, 2009; Schoenfeld, Segal, $\&$ Borgia, 2017). Penelitian ini akan berfokus pada self-efficacy dan outcome expectation untuk memprediksi niat mahasiswa akuntansi untuk menjalani karir sebagai akuntan publik. Penelitian ini akan berkontribusi dengan menguji model SCCT pada sebelum dan setelah mahasiswa mengambil matakuliah auditing, yang belum pernah dilakukan oleh penelitian-penelitian sebelumnya. Tujuan dari penelitian ini adalah untuk 
melihat apakah pengaruh intervensi pendidikan melalui matakuliah auditing dapat memperkuat hubungan antara self-efficacy dan outcome expectation terhadap niat mahasiswa untuk bekerja sebagai akuntan publik.

\section{TINJAUAN PUSTAKA}

\subsection{Social Cognitive Career Theory}

Social cognitive career theory (SCCT) dikemukakan oleh Lent et al. (1994) memuat pertanyaan bagaimana ketertarikan pada suatu karir berkembang dari self-efficacy, bagaimana pilihan terkait karir dibuat, dan bagaimana kinerja diraih. Model SCCT dibangun dari social cognitive theory (Bandura, 1986) yang menyediakan kerangka komprehensif untuk menjelaskan suatu proses dinamis untuk mewujudkan pilihan akademik atau pilihan karir. Proses SCCT sendiri dipengaruhi oleh berbagai input personal dan faktor-faktor lingkungan dan situasional yang saling berhubungan dan berubah setiap waktu. Teori ini merumuskan hubungan langsung antara self-efficacy, outcome expectation, dan goals. Semakin kuat keyakinan akan self-efficacy dan outcome expectation seseorang, maka akan semakin memungkinkan seseorang tersebut untuk meraih tujuan karirnya. Ketika perubahan terjadi pada kepercayaan dan keyakinan diri seseorang akan mengakibatkan perubahan pada tujuan karirnya. Model tersebut juga merumuskan semakin tinggi self-efficacy seseorang akan menghasilkan outcome expectation yang tinggi pula.

Self-efficacy didefinisikan sebagai keyakinan, pemikiran, dan perasaan individu tentang kemampuan personalnya yang mempengaruhi bagaimana mereka menampilkan kinerjanya (Bandura \& Adams, 1977). Konsep ini merefleksikan pemikiran terdalam seseorang tentang apakah mereka memiliki kemampuan untuk menyelesaikan suatu pekerjaan yang dianggap penting serta keyakinan bahwa mereka dapat secara aktif mengubah kemampuan tersebut menjadi hasil yang diinginkan (Bandura \& Wood, 1989). Dari kedua definisi tersebut dapat disimpulkan bahwa selfefficacy merupakan keyakinan atau kepercayaan seseorang akan kemampuan dirinya untuk melakukan suatu tugas, menghasilkan dan mengimplementasikan suatu tindakan untuk menunjukkan kemampuannya.

Bandura (1992) mengemukakan bahwa self-efficacy seseorang didasarkan pada empat sumber, di antaranya adalah: (1) Mastery experience. Kesuksesan membangun keyakinan yang kuat atas efficacy personal seseorang karena didasarkan pada pengalaman yang otentik. Pengalaman akan kesuksesan menyebabkan self-efficacy seseorang meningkat, sementara kegagalan yang berulang akan menurunkan self-efficacy seseorang; (2) Modelling. Self-efficacy juga dipengaruhi oleh pengalaman orang lain. Keberhasilan individu lain dalam suatu bidang tertentu akan sangat mungkin meningkatkan self-efficacy individu tersebut pada bidang yang sama. Dampak dari permodelan akan self-efficacy tersebut dipengaruhi oleh perasaan akan banyaknya persamaan dengan orang lain yang menjadi role model. Semakin besar persamaan dengan role model-nya maka akan semakin besar pengaruh persuasif model untuk sukses atau gagal. (3) Social Persuasion. Persuasi sosial adalah cara ketiga untuk memperkuat keyakinan seseorang atas apa yang mereka punyai untuk sukses. Orang yang dipersuasi 
secara verbal bahwa mereka mempunyai kapabilitas untuk menguasai suatu aktivitas akan mungkin untuk meraih apa yang diinginkan. (4) Judgement of own physiological state. Keadaan fisiologis juga mempengaruhi kemampuan individu dalam menyelesaikan tugasnya. Keadaan fisiologis mencakup gejolak emosi dan keadaan fisik seseorang menjadi isyarat bagi seseorang bahwa apakah suatu situasi berada diluar kemampuannya.

Bandura \& Adams (1977) juga mengungkapkan bahwa self-efficacy seseorang dapat dilihat dari tiga dimensi, yaitu: 1) Level. Tingkat atau level self-efficacy seseorang dalam mengerjakan tugas tentunya berbeda sesuai dengan tingkat kesulitannya. Seseorang memiliki tingkat self-efficacy yang tinggi pada tugas yang mudah atau juga pada tugas yang membutuhkan kompetensi tinggi. Seseorang yang memiliki self-efficacy tinggi cenderung memilih tugas dengan tingkat kesulitan sesuai dengan kemampuannya; 2) Generality. Generality berkaitan dengan penguasaan seseorang terhadap suatu pekerjaan. Seseorang dengan self-efficacy tinggi akan dapat menguasai beberapa bidang sekaligus untuk menyelesaikan suatu pekerjaan, sedangkan orang dengan self-efficacy rendah hanya mampu menguasai sedikit bidang dalam menyelesaikan suatu pekerjaan; 3) Strength. Dimensi ini lebih menekankan pada tingkat kekuatan seseorang terhadap keyakinannya. Self-efficacy menjadi dasar seseorang untuk melakukan usaha dengan keras apapun rintangannya.

Outcome expectation adalah konsekuensi yang diantisipasi atas tindakan tertentu, termasuk didalamnya pandangan sosial baik itu negatif atau positif, misalnya persetujuan orang lain, materi yang diraih, dan gengsi (Lent et al., 2016). Sedangkan goal merujuk pada niat seseorang untuk melakukan sesuatu terhadap karirnya misalnya untuk mengembangkan karirnya (Lent et al., 2016). Menurut model SCCT goal didefinisikan secara luas seperti rencana, aspirasi, atau intention (niat). Goal adalah tekad seseorang untuk melakukan aktifitas tertentu (Bandura, 1986). Pada penelitian ini, goal didefinisikan sebagai intention atau niat mahasiswa untuk bekerja sebagai akuntan publik.

\subsection{Pengembangan Hipotesis}

\subsubsection{Hubungan Self Efficacy dan Intention}

Self-efficacy telah terbukti mempengaruhi berbagai ragam perilaku seperti pengambilan keputusan, pilihan atau minat dan pengembangan karir (Anderson \& Betz, 2001; Iskandar \& Sanusi, 2011; Pihie, 2009; Segal, Borgia, \& Schoenfeld, 2002; Silvia, 2003). Sejauh ini penelitian sebelumnya telah menguji pengaruh self-efficacy dalam memprediksi niat mahasiswa untuk mewujudkan karir di profesi akuntansi secara umum (Ahmad et al., 2015; James \& Hill, 2009). Ahmad et al. (2015) menemukan bahwa self-efficacy terbukti mempengaruhi niat berkomitmen mahasiswa akuntansi untuk bekerja sebagai akuntan. Hal ini diperkuat oleh James \& Hill (2009) yang menemukan bahwa self-efficacy yang rendah adalah kontributor yang mungkin menurunkan jumlah akuntan berlatarbelakang Afrika-Amerika di USA.

Model SCCT menekankan pada peran self-efficacy dalam mempengaruhi niat seseorang untuk mewujudkan karir yang diinginkannya. Berdasarkan Bandura (1986) 
kemungkinan untuk mewujudkan karir yang diinginkan adalah bagian dari keyakinan dan kepercayaan diri seseorang. Dalam penelitian ini self-efficacy digunakan untuk memprediksi niat mahasiswa untuk bekerja sebagai akuntan publik.

Intervensi berupa pendidikan dapat memfasilitasi peningkatan self-efficacy melalui sumber-sumbernya termasuk mastery experience, modeling, social persuasion, dan judgement of own physiological state. Contoh, dalam hal mastery experience, pengalaman yang otentik akan kesuksesan menyebabkan self-efficacy seseorang meningkat (Bandura, 1992). Pengalaman ini dapat diberikan melalui pendidikan, misalnya pemberian tugas dan praktikum, serta terlibat secara langsung dalam pekerjaan yang akan dijalani. Adanya tugas dan praktikum adalah bentuk stimulus seseorang untuk merasakan pengalaman yang nantinya berpotensi untuk meningkatkan self-efficacy (Subramaniam \& Freudenberg, 2007). Schunk (1985) berpendapat bahwa adanya umpan balik dari pengajar selama proses pembelajaran dapat membuat seseorang menyadari bahwa dia mengalami kemajuan, baik dari sisi keterampilan dan pengetahuan, yang selanjutnya akan meningkatkan motivasi dan self-efficacy dari mahasiswa.

Beberapa penelitian membuktikan bahwa pendidikan berperan penting untuk meningkatkan self-efficacy. Wilson et al. (2007) dalam penelitiannya tentang pendidikan kewirausahaan untuk meningkatkan self-efficacy membuktikan bahwa pendidikan kewirausahaan berpengaruh pada peningkatan self-efficacy yang dimoderasi oleh gender. Penemuan tersebut menegaskan bahwa dengan menyediakan akses pendidikan kewirausahaan terutama untuk pengusaha wanita dapat meningkatkan level self-efficacy dan minat untuk memulai usaha sendiri. Dalam konteks penelitian pendidikan akuntansi, penelitian Subramaniam \& Freudenberg (2007) menunjukkan bahwa program Work Integrated Learning (WIL) berpengaruh pada peningkatan selfefficacy mahasiswa. Program WIL digunakan untuk meningkatkan kompetensi mahasiswa dengan mengkombinasikan dan mengintegrasikan pembelajaran dengan aplikasi di tempat kerja, tanpa memperhatikan integrasi ini terjadi di industri atau universitas dan apakah ini nyata atau hanya simulasi.

Dalam penelitian ini, pendidikan melalui matakuliah auditing diharapkan dapat meningkatkan self-efficacy mahasiswa. Pada mata kuliah auditing, mahasiswa diberikan dasar-dasar pengauditan sebagai bekal mereka dalam meningkatkan kompetensi sebagai calon akuntan publik. Mahasiswa juga mendapatkan umpan balik dari pengajar yang akan meningkatkan self-efficacy mahasiwa. Berdasarkan model SCCT, mahasiswa dengan self-efficacy yang tinggi akan mempengaruhi niatnya untuk bekerja sebagai akuntan publik. Adanya pembekalan pendidikan berupa matakuliah auditing akan memperkuat pengaruh positif self-efficacy dan niat mahasiswa bekerja sebagai akuntan publik setelah mengikuti matakuliah auditing. Ketika terjadi perubahan pada self-efficacy berarti akan terjadi perubahan pada keyakinan dan kepercayaan diri mahasiswa, sehingga berpotensi untuk merubah minat mahasiswa akan prospek karirnya. Dari uraian di atas dapat disusun hipotesis sebagai berikut:

$\mathbf{H}_{1}$ : Pengaruh positif self-efficacy terhadap niat mahasiswa untuk bekerja sebagai akuntan publik lebih kuat setelah mengambil mata kuliah auditing. 


\subsubsection{Hubungan Outcome Expectation dan Intention}

Penggunaan model SCCT dalam ranah pendidikan akuntansi masih jarang dilakukan. James \& Hill (2009) dan Hayes \& Credle (2008) telah menggunakan model SCCT untuk menyelidiki ketertarikan mahasiswa Afrika-Amerika kepada jurusan akuntansi dan akuntan publik sebagai sebuah profesi. Temuan Hayes \& Credle (2008) mengindikasikan bahwa ada hubungan positif antara self-efficacy dan outcome expectation dengan pilihan karir sebagai akuntan publik. Penelitian Schoenfeld et al. (2017) juga membuktikan kemapanan model SCCT untuk memprediksi niat mahasiswa untuk mencapai karir sebagai CPA (Certified Public Accountant). Mahasiswa dengan selfefficacy yang tinggi untuk menjadi CPA berprospek lebih tinggi untuk mewujudkan cita-citanya sebagai CPA dan semakin tinggi outcome expectation untuk menjadi CPA juga berhubungan kuat untuk mewujudkan tujuan sebagai CPA.

Outcome expectation berperan penting dalam memotivasi individu untuk mencapai tujuannya. Jika self-efficacy berkenaan dengan "Akankah saya bisa melakukan ini?", outcome expectation berkenaan dengan "Jika saya melakukan ini, apa hasilnya?" (Lent et al, 1994). Keyakinan akan hasil yang akan dicapai merupakan bentuk dari ekspektasi seseorang terhadap konsekuensi atas apa yang dilakukan (Schoenfeld et al., 2017). Ekspektasi akan hasil jika seseorang bekerja sebagai akuntan publik ini dapat berupa tingginya pendapatan yang diterima, keamanan kerja yang lebih baik, potensi untuk kemajuan, dan gengsi sosial. Beberapa penelitian membuktikan kemapanan model SCCT dalam memprediksi niat seseorang untuk mewujudkan karir berdasarkan outcome expectation-nya (Schoenfeld et al., 2017; Diegelman \& Subich, 2001). Karena seseorang akan cenderung mengembangkan minatnya suatu aktivitas jika mereka percaya pada hasil yang akan mereka dapatkan, sebaliknya seseorang akan berkurang minatnya jika mereka merasa hasilnya mungkin negatif (Lent et al, 1994).

Beberapa penelitian menyebutkan bahwa outcome expectation seseorang bisa dipengaruhi dalam bentuk seperti intervensi (Diegelman and Usbich, 2001) yang nantinya akan berpengaruh terhadap niatnya. Seseorang yang memiliki self-efficacy yang tinggi bisa saja mengurungkan niatnya untuk mewujudkan tujuan tertentu karena persepsi mereka akan hambatan-hambatan tertentu dan persepsi mereka akan outcome expectation yang negatif (Swanson \& Woitke, 1997). Karenanya dibutuhkan intervensi tertentu untuk merubah outcome expectation seseorang yang nantinya berpengaruh terhadap niat untuk mewujudkan karirnya. Diegelman \& Usbich (2001) membuktikan bahwa perubahan outcome expectation setelah intervensi dapat mempengaruhi perubahan niat dalam mewujudkan niat mahasiswa untuk masuk ke jurusan psikologi. Intervensi dalam penelitian tersebut berupa persuasi verbal yang disajikan dalam bentuk presentasi dan diskusi tentang peluang karir, hasil positif yang mungkin didapatkan dari profesi tersebut, persepsi positif atas jurusan psikologi, dan tingkat kepuasan lulusan psikologi dengan karir mereka.

Dalam penelitian ini, intervensi yang digunakan untuk merubah persepsi atas outcome expectation adalah dengan mengambil matakuliah auditing. Pada matakuliah auditing, dosen memiliki kesempatan untuk melakukan persuasi verbal dengan memperkenalkan profesi akuntan publik serta memberikan informasi atas outcome 
expectation yang mungkin mahasiswa dapatkan jika bekerja sebagai akuntan publik. Berdasarkan model SCCT, mahasiswa dengan outcome expectation yang positif akan mempengaruhi niatnya untuk bekerja sebagai akuntan publik. Adanya intervensi ketika mengikuti mata kuliah auditing akan memperkuat pengaruh positif outcome expectation dan niat mahasiswa bekerja sebagai akuntan publik. Dari uraian di atas dapat disusun hipotesis sebagai berikut:

$\mathrm{H}_{2}$ : Pengaruh positif outcome expectation terhadap niat mahasiswa untuk bekerja sebagai akuntan publik lebih kuat setelah mengambil mata kuliah auditing

\subsubsection{Hubungan Self-efficacy dan Outcome Expectation}

Sesuai dengan teori SCCT, keyakinan atas self-efficacy tidak hanya berpengaruh pada pencapaian tujuan terkait pengambilan keputusan atas karir seseorang. Self-efficacy juga berpengaruh pada outcome expectation seseorang jika ia mewujudkan niatnya (Hayes \& Credle, 2008; James \& Hill, 2009; Lent et al., 1994, 2016; Lent, Ireland, Penn, Morris, \& Sappington, 2017; Schoenfeld et al., 2017). Berdasarkan Lent et al. (1994) seseorang mungkin mengantisipasi hasil yang mungkin ia dapatkan di masa depan dengan mengevaluasi hasil dari tindakannya di masa lalu, mengamati pengalaman orang lain atas konsekuensi yang mungkin muncul dari suatu tindakan, dan menghadirkan pihak ketiga sebagai penguatan. Jadi, outcome expectation dapat dipengaruhi oleh self-efficacy pada situasi ketika hasil yang diinginkan seseorang tersebut berhubungan erat dengan kualitas kinerjanya (Bandura, 1986). Mahasiswa yang merasa mampu berkinerja baik berharap untuk menerima pujian atau umpan balik yang positif dari pengajarnya, yang juga berperan dalam meningkatkan self-efficacy (Schunk, 1985). Dalam penelitian ini SCCT merumuskan bahwa self-efficacy menjadi dasar penting untuk outcome expectation karena secara umum seseorang dengan self-efficacy yang tinggi berharap untuk menerima hasil yang diinginkan ketika berhasil mewujudkan karirnya.

Berdasarkan social cognitive theory (Bandura, 1986), salah satu penentu tinggi rendahnya self efficacy seseorang adalah social persuasion. Persuasi sosial merupakan cara untuk memperkuat keyakinan seseorang atas apa yang mereka punyai untuk sukses. Orang yang dipersuasi secara verbal bahwa mereka mempunyai kapabilitas untuk menguasai suatu aktivitas akan mungkin untuk meraih apa yang diinginkan. Melalui mata kuliah auditing, pendidik memiliki kesempatan untuk memberi keyakinan anak didiknya bahwa mereka memiliki kapabilitas untuk menjadi akuntan publik, sehingga ketika mahasiswa mengambil mata kuliah auditing, self-efficacy mahasiswa tersebut akan meningkat. Ketika terjadi perubahan pada self-efficacy berarti akan terjadi perubahan pada keyakinan dan kepercayaan diri mahasiswa, sehingga berpotensi untuk merubah outcome expectation mahasiswa akan apa yang mungkin ia dapatkan jika mewujudkan karir sebagai akuntan publik. Dari uraian di atas dapat disusun hipotesis sebagai berikut:

$\mathrm{H}_{3}$ : Pengaruh positif self efficacy terhadap outcome expectation mahasiswa jika ia mewujudkan karimya sebagai akuntan publik lebih kuat setelah mengambil mata kuliah auditing. 
Berdasarkan telaah literatur dan pengembangan hipotesis di atas, dapat dirumuskan model penelitian yang diadaptasi dari model social cognitive career theory (Lent et al, 1994).

\section{Gambar 1. Model Penelitian}

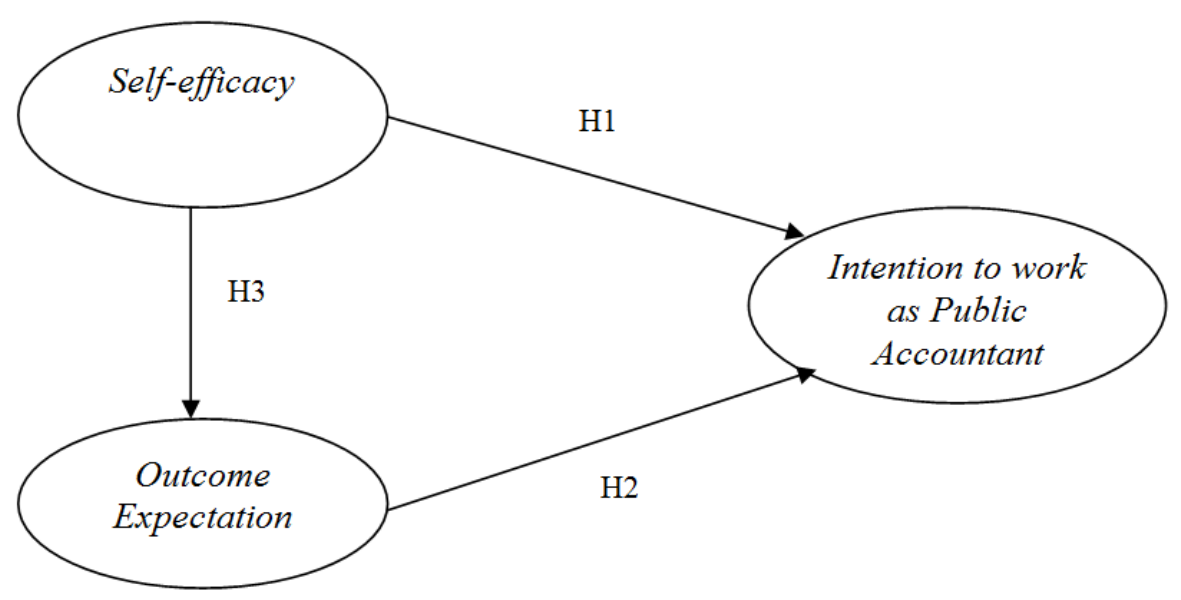

Diadaptasi dari Social Cognitive Career Theory (Lent et al, 1994)

\section{METODE PENELITIAN}

Populasi dari penelitian ini adalah mahasiswa akuntansi di Universitas di Jabodetabek (Jakarta, Bogor, Depok, Tangerang, dan Bekasi). Penelitian ini menggunakan metode survey dengan kuesioner sebagai instrumen penelitian. Sampel dari penelitian ini adalah mahasiswa akuntansi pada sebelum dan sesudah mengambil mata kuliah auditing I dari tiga Universitas di Jabodetabek. Pengujian hipotesis 1-3 dalam penelitian ini adalah dengan menggunakan teknik analisis data SEM (Structural Equation Modelling) yang dioperasikan dengan menggunakan program STATA.

Penelitian ini mempunyai tiga variabel laten, yaitu self-efficacy, outcome expectation (harapan akan hasil) dan intention, dan 22 variabel teramati. Variabel laten merupakan variabel abstrak yang hanya bisa diamati secara tidak langsung melalui pengaruhnya terhadap variabel teramati. Variabel laten dibedakan menjadi dua, yakni variabel laten eksogen (independen) dan variabel laten endogen (dependen) (Wijanto, 2008). Selfefficacy dan outcome expectation merupakan variabel laten eksogen, sedangkan intention merupakan variabel laten endogen. Variabel teramati merupakan item-item pertanyaan dalam kuesioner penelitian yang digunakan sebagai indikator dari tiap variabel laten yang dapat diukur atau diamati secara langsung.

Self-efficacy digunakan untuk mengukur tingkat kepercayaan diri mahasiswa akan kemampuannya untuk mewujudkan karir sebagai akuntan publik. Pengukuran selfefficacy berfokus pada task-specific dengan kuesioner yang diadopsi dari penelitian (Subramaniam \& Freudenberg, 2007). Variabel self-efficacy diukur dengan 8 item variabel teramati yang mewakili pernyataan seperti "saya percaya diri mengawali karir sebagai akuntan publik". Skala yang digunakan adalah 7 skala likert dengan 1 yang berarti "sangat tidak setuju" dan 7 yang mengindikasikan "sangat setuju". 
Outcome expectation (harapan akan hasil) adalah konsekuensi yang diantisipasi atas tindakan tertentu, termasuk didalamnya pandangan sosial baik itu negatif atau positif, misalnya persetujuan orang lain, materi yang diraih, dan gengsi (Lent et al., 2016). Variabel ini digunakan untuk mengukur hasil yang diharapkan mahasiswa dari profesi akuntan publik. Pengukuran outcome expectation menggunakan kuesioner yang diadopsi dari penelitian (Schoenfeld et al., 2017). Variabel outcome expectation diukur dengan menggunakan 8 item variabel teramati yang mewakili harapan mereka akan hasil jika berprofesi sebagai akuntan publik, seperti "pendapatan tinggi" dan "potensi untuk maju dan berkembang”. Skala yang digunakan adalah 7 skala likert dengan 1 yang mengindikasikan "sangat tidak penting" dan 7 yang berarti "sangat penting".

Intention merupakan variabel yang mengukur niat mahasiswa untuk bekerja sebagai akuntan publik. Pengukuran intention menggunakan kuesioner yang diadopsi dari penelitian Ahmad et al. (2015) dan Hayes \& Credle (2008). Variabel intention diukur dengan 6 item variabel teramati yang mewakili niat mahasiswa untuk bekerja sebagai akuntan publik, seperti pernyataan "saya berniat untuk bekerja sebagai akuntan publik setelah saya lulus”. Skala yang digunakan adalah 7 skala likert dengan 1 yang berarti "sangat tidak setuju" dan 7 yang mengindikasikan "sangat setuju". Tabel 1 menujukkan secara lebih rinci operasionalisasi variabel laten dan variabel teramati untuk masingmasing variabel.

Tabel 1. Operasionalisasi Variabel

\begin{tabular}{|c|c|c|c|}
\hline $\begin{array}{c}\text { Variabel } \\
\text { Laten }\end{array}$ & \multicolumn{2}{|r|}{ Variabel Teramati } & Skala Pengukuran \\
\hline \multirow{8}{*}{ Self-Efficacy } & SEF-1 & $\begin{array}{l}\text { Saya percaya diri mengawali karir sebagai akuntan } \\
\text { publik. }\end{array}$ & \multirow{8}{*}{$\begin{array}{l}\text { Skala likert } \\
\text { 1=Sangat tidak } \\
\text { setuju } \\
\text { 2=Tidak setuju } \\
\text { 3=Agak tidak setuju } \\
\text { 4=Ragu-ragu } \\
\text { 5=Agak setuju } \\
\text { 6= Setuju } \\
\text { 7=Sangat setuju }\end{array}$} \\
\hline & SEF-2 & $\begin{array}{l}\text { Saya harap saya dapat bekerja dengan baik sebagai } \\
\text { akuntan publik }\end{array}$ & \\
\hline & SEF-3 & $\begin{array}{l}\text { Saya punya keyakinan pribadi bahwa saya bisa } \\
\text { mendapatkan sebuah posisi di pekerjaan akuntan } \\
\text { publik. }\end{array}$ & \\
\hline & SEF-4 & $\begin{array}{l}\text { Saya mempunyai kemampuan untuk untuk } \\
\text { mempelajari keahlian yang dibutuhkan bagi } \\
\text { pekerjaan akuntan publik. }\end{array}$ & \\
\hline & SEF-5 & $\begin{array}{l}\text { Saya yakin dalam menyelesaikan tugas audit yang } \\
\text { ditugaskan ke saya. }\end{array}$ & \\
\hline & SEF-6 & $\begin{array}{l}\text { Saya yakin dalam menggunakan pendekatan yang } \\
\text { diterima umum sebagai akuntan publik profesional. }\end{array}$ & \\
\hline & SEF-7 & $\begin{array}{l}\text { Saya yakin akan kemampuan saya untuk } \\
\text { berkomunikasi dengan klien dan kolega dengan cara } \\
\text { yang efektif. }\end{array}$ & \\
\hline & SEF-8 & $\begin{array}{l}\text { Saya percaya bahwa saya bisa sukses sebagai akuntan } \\
\text { publik. }\end{array}$ & \\
\hline \multirow{2}{*}{$\begin{array}{l}\text { Outcome } \\
\text { Expectation }\end{array}$} & OE-1 & Pendapatan tinggi & \multirow{2}{*}{$\begin{array}{l}\text { Skala likert } \\
\text { 1=Sangat tidak } \\
\text { penting } \\
\text { 2=Tidak penting }\end{array}$} \\
\hline & OE-2 & Potensi untuk maju dan berkembang & \\
\hline
\end{tabular}




\begin{tabular}{|c|c|c|c|}
\hline & OE-3 & Tunjangan dan bonus yang menjanjikan & \multirow{2}{*}{$\begin{array}{l}3=\text { Agak tidak } \\
\text { penting } \\
\text { 4=Ragu-ragu } \\
5=\text { Agak Penting } \\
6=\text { Penting } \\
7=\text { Sangat Penting }\end{array}$} \\
\hline & OE-4 & Keamanan kerja & \\
\hline \multirow{6}{*}{$\begin{array}{l}\text { Intention to } \\
\text { work }\end{array}$} & INW-1 & $\begin{array}{l}\text { Saya berniat untuk bekerja sebagai akuntan publik } \\
\text { setelah saya lulus }\end{array}$ & \multirow{6}{*}{$\begin{array}{l}\text { Skala likert } \\
\text { 1=Sangat tidak } \\
\text { setuju } \\
\text { 2=Tidak setuju } \\
\text { 3=Agak tidak setuju } \\
\text { 4=Ragu-ragu } \\
\text { 5=Agak setuju } \\
\text { 6= Setuju } \\
7=\text { Sangat setuju }\end{array}$} \\
\hline & INW-2 & $\begin{array}{l}\text { Memasuki karir sebagai akuntan publik adalah } \\
\text { sesuatu yang saya rencanakan }\end{array}$ & \\
\hline & INW-3 & $\begin{array}{l}\text { Saya akan mencoba untuk masuk sebagai akuntan } \\
\text { publik setelah saya lulus }\end{array}$ & \\
\hline & INW-4 & Penting bagi saya untuk menjadi akuntan publik. & \\
\hline & INW-5 & $\begin{array}{l}\text { Saya percaya bahwa akuntan publik adalah profesi } \\
\text { yang ideal untuk hidup. }\end{array}$ & \\
\hline & INW-6 & $\begin{array}{l}\text { Saya berniat untuk bekerja keras untuk membuat } \\
\text { profesi akuntan publik berhasil. }\end{array}$ & \\
\hline
\end{tabular}

\section{HASIL DAN PEMBAHASAN}

\subsection{Statistik Deskriptif Sampel}

Pengumpulan data dilakukan pada awal bulan September 2017 hingga akhir Januari 2018. Survei dilakukan sebelum mahasiswa mengambil matakuliah Auditing 1 dan setelah mahasiswa menyelesaikan mata kuliah Auditing 1. Sampel dalam penelitian ini adalah mahasiswa dari tiga Universitas di Jabodetabek, yakni dua dari Universitas Swasta dan satu dari Universitas Negeri. Tabel 2 menunjukkan statistik deskriptif responden sebelum dan sesudah mengambil matakuliah auditing.

Tabel 2. Deskripsi Sampel

\begin{tabular}{|l|c|c|c|c|}
\hline \multirow{2}{*}{ Item } & \multicolumn{2}{|c|}{ Sebelum } & \multicolumn{2}{c|}{ Sesudah } \\
\cline { 2 - 5 } & Frekuensi & $\%$ & Frekuensi & $\%$ \\
\hline Asal Universitas & 26 & $11,1 \%$ & 22 & $10,2 \%$ \\
\hline Negeri & 208 & $88,9 \%$ & 193 & $89,8 \%$ \\
\hline Swasta & 59 & $25,2 \%$ & 44 & $20,5 \%$ \\
\hline Gender & 134 & $57,3 \%$ & 112 & $52,1 \%$ \\
\hline Pria & 41 & $17,5 \%$ & 59 & $27,4 \%$ \\
\hline Wanita & \multicolumn{5}{|l}{} \\
\hline Not stated & 222 & $94,9 \%$ & 210 & $97,7 \%$ \\
\hline Semester & 1 & $0,4 \%$ & 1 & $0,5 \%$ \\
\hline 5 & 11 & $4,7 \%$ & 4 & $1,9 \%$ \\
\hline 7 & 1 & $0,4 \%$ & 0 & $0 \%$ \\
\hline Lainnya & 10 & $4,3 \%$ & 8 & $3,7 \%$ \\
\hline IPK & 54 & $23,1 \%$ & 49 & $22,8 \%$ \\
\hline$<2,0$ & 80 & $34,2 \%$ & 71 & $33 \%$ \\
\hline $2,01-2,50$ & 88 & $37,6 \%$ & 85 & $39,5 \%$ \\
\hline $2,51-3,00$ & 1 & $0,4 \%$ & 2 & $0.9 \%$ \\
\hline $3,01-3,50$ & \multicolumn{5}{|l|}{} \\
\hline $3,51-4,00$ & \multicolumn{5}{|l|}{} \\
\hline Not stated & \multicolumn{5}{|l|}{} \\
\hline
\end{tabular}

Sumber: Hasil olahan data primer, 2018 
Total sampel untuk survey sebelum mata kuliah auditing adalah 237 mahasiswa, namun yang dapat diolah sebesar 234 sampel. Total sampel untuk survey setelah mengambil mata kuliah auditing menurun menjadi 216 dan yang dapat diolah sebesar 215 sampel. Adanya penurunan jumlah sampel pada pengambilan data setelah mahasiswa mengambil mata kuliah Auditing 1 dikarenakan survey dilakukan pada hari terakhir perkuliahan di semester 5 , sehingga banyak dari responden yang tidak masuk kuliah. Responden penelitian ini sebagian besar adalah mahasiswa yang berasal dari universitas swasta sebesar sekitar 89\%, selebihnya adalah mahasiswa dari universitas negeri. Mahasiswa perempuan mendominasi sampel hingga lebih dari 50\%, sedangkan mahasiswa pria hanya sekitar 20\%, dan yang lainnya tidak menyatakan laki-laki atau perempuan. Sebagian besar sampel merupakan mahasiswa semester 5, karena mata kuliah Auditing 1 untuk sebagian Universitas di Jabodetabek memang diselenggarakan di semester 5. Pada persebaran IPK dapat dilihat bahwa persentase mahasiswa yang memiliki IPK di atas 3,01 mencapai lebih dari 70\% dari total responden. Hal ini mengindikasikan bahwa sebagian besar mahasiswa responden memiliki kemampuan kognitif yang baik yang bisa saja berpengaruh pada tingginya tingkat self-efficacy mereka (Ismail et al., 2017)

\subsection{Penilaian Model Pengukuran}

Pengujian hipotesis dilakukan dengan SEM (Sructural Equation Modeling) yang dijalankan dengan program STATA untuk mendapatkan pengukuran estimasi parameter dan model struktural. Hasil dari SEM mengindikasikan kecocokan model yang cukup baik, dengan melihat nilai CFI, TLI, dan SRMR yang marginal fit dan good fit. Hasil uji goodness of fit (GOF) secara detail beserta batas tingkat kecocokannya dapat dilihat di Tabel 3.

Tabel 3. Goodness of Fit Keseluruhan Model

\begin{tabular}{|c|c|c|c|c|c|}
\hline \multirow{2}{*}{$\begin{array}{c}\text { Ukuran } \\
\text { GOF }\end{array}$} & \multirow{2}{*}{$\begin{array}{c}\text { Batas Tingkat } \\
\text { Kecocokan } \\
\text { yang baik }\end{array}$} & \multicolumn{2}{|c|}{ Sebelum Kuliah Audit } & \multicolumn{2}{|c|}{ Sesudah Kuliah Audit } \\
\hline & & $\begin{array}{c}\text { Hasil } \\
\text { Estimasi }\end{array}$ & $\begin{array}{c}\text { Tingkat } \\
\text { Kecocokan }\end{array}$ & $\begin{array}{c}\text { Hasil } \\
\text { Estimasi }\end{array}$ & $\begin{array}{c}\text { Tingkat } \\
\text { Kecocokan }\end{array}$ \\
\hline $\begin{array}{l}\text { Chi- } \\
\text { Square }\end{array}$ & $\begin{array}{l}\text { Nilai yang kecil, } \\
\text { dengan } p>0,05\end{array}$ & 0,000 & Poor fit & 0,000 & Poor fit \\
\hline RMSEA & $\leq 0,08$ & 0,111 & Poor fit & 0,104 & Poor fit \\
\hline AIC & Nilai yang kecil & 9037,519 & Poor fit & 8849,541 & Poor fit \\
\hline $\mathrm{BIC}$ & Nilai yang kecil & 9213,74 & Poor fit & 9041,135 & Poor fit \\
\hline $\mathrm{CFI}$ & $\geq 0,90$ & 0,891 & Marginal Fit & 0,916 & Good Fit \\
\hline TLI & $\geq 0,90$ & 0,871 & Marginal Fit & 0,903 & Good Fit \\
\hline SRMR & $\leq 0,05$ & 0,065 & Marginal Fit & 0,066 & Marginal Fit \\
\hline
\end{tabular}

Sumber: Hasil olahan data primer, 2018

Setelah kecocokan model dan data secara keseluruhan adalah baik, maka langkah berikutnya adalah evaluasi model pengukuran. Model pengukuran dianggap mempunyai validitas jika memenuhi kriteria standardize loading factor $\geq 0,50$. Jika ada 
nilai muatan faktor standar lebih kecil dari batas kritis tersebut, maka variabel teramati terkait bisa dihapuskan dari model (Hulland, 1999). Pada penelitian ini beberapa variabel teramati dihapuskan karena memiliki standardize loading factor yang kurang dari 0,50, karena eliminasi indikator yang dibawah standar ini dapat meningkatkan nilai composite reliability (Henseler, Ringle, \& Sinkovics, 2009). Evaluasi terhadap reliabilitas model pengukuran dilakukan dengan menganalisis nilai composite reliability (CR) dan variance extracted (VE). Seperti dapat dilihat pada tabel 4, semua nilai composite reliability pada konstruk bernilai lebih dari 0,6 dan semua nilai dari variance extracted melebihi titik kritis sebesar 0,5 seperti yang dianjurkan oleh Henseler et al. (2009).

Tabel 4. Pengukuran Validitas dan Reliabilitas Model Struktural

\begin{tabular}{|c|c|c|c|c|c|c|c|}
\hline \multirow{3}{*}{ Items } & \multicolumn{3}{|c|}{ Sebelum Kuliah Auditing } & \multicolumn{3}{|c|}{ Setelah Kuliah Auditing } & \multirow{3}{*}{ Keterangan } \\
\hline & \multirow{2}{*}{$\begin{array}{c}\text { Validitas } \\
\text { Loading } \\
\text { Factors }\end{array}$} & \multicolumn{2}{|c|}{ Reliabilitas } & \multirow{2}{*}{$\begin{array}{l}\text { Validitas } \\
\text { Loading } \\
\text { Factors }\end{array}$} & \multicolumn{2}{|c|}{ Reliabilitas } & \\
\hline & & $\mathrm{CR}$ & VE & & $\mathrm{CR}$ & VE & \\
\hline Self-Efficacy & & 0,93 & 0,64 & & 0,95 & 0,70 & Reliabilitas Baik \\
\hline SEF1 & 0,85 & & & 0,77 & & & Validitas Baik \\
\hline SEF2 & 0,77 & & & 0,81 & & & Validitas Baik \\
\hline SEF3 & 0,85 & & & 0,92 & & & Validitas Baik \\
\hline SEF4 & 0,76 & & & 0,87 & & & Validitas Baik \\
\hline SEF5 & 0,74 & & & 0,86 & & & Validitas Baik \\
\hline SEF6 & 0,75 & & & 0,89 & & & Validitas Baik \\
\hline SEF7 & Deleted & & & 0,65 & & & Validitas Baik \\
\hline SEF8 & 0,85 & & & 0,89 & & & Validitas Baik \\
\hline $\begin{array}{l}\text { Outcome } \\
\text { Expectation }\end{array}$ & & 0,76 & 0,52 & & 0,82 & 0,54 & Reliabilitas Baik \\
\hline OE1 & 0,8 & & & 0,91 & & & Validitas Baik \\
\hline OE2 & 0,54 & & & 0,71 & & & Validitas Baik \\
\hline OE3 & 0,79 & & & 0,69 & & & Validitas Baik \\
\hline OE4 & Deleted & & & 0,6 & & & Validitas Baik \\
\hline Intention & & 0,91 & 0,63 & & 0,94 & 0,74 & Reliabilitas Baik \\
\hline INW1 & 0,89 & & & 0,94 & & & Validitas Baik \\
\hline INW2 & 0,87 & & & 0,94 & & & Validitas Baik \\
\hline INW3 & 0,85 & & & 0,93 & & & Validitas Baik \\
\hline INW4 & 0,76 & & & 0,83 & & & Validitas Baik \\
\hline INW5 & 0,59 & & & 0,64 & & & Validitas Baik \\
\hline INW6 & 0,77 & & & 0,84 & & & Validitas Baik \\
\hline
\end{tabular}

Sumber: Hasil olahan data primer, 2018

\subsection{Temuan}

Gambar 2 dan Gambar 3 menunjukkan hasil output path diagram atas model penelitian. 
Gambar 2. Path Diagram dari Model Penelitian Sebelum Mata Kuliah Auditing

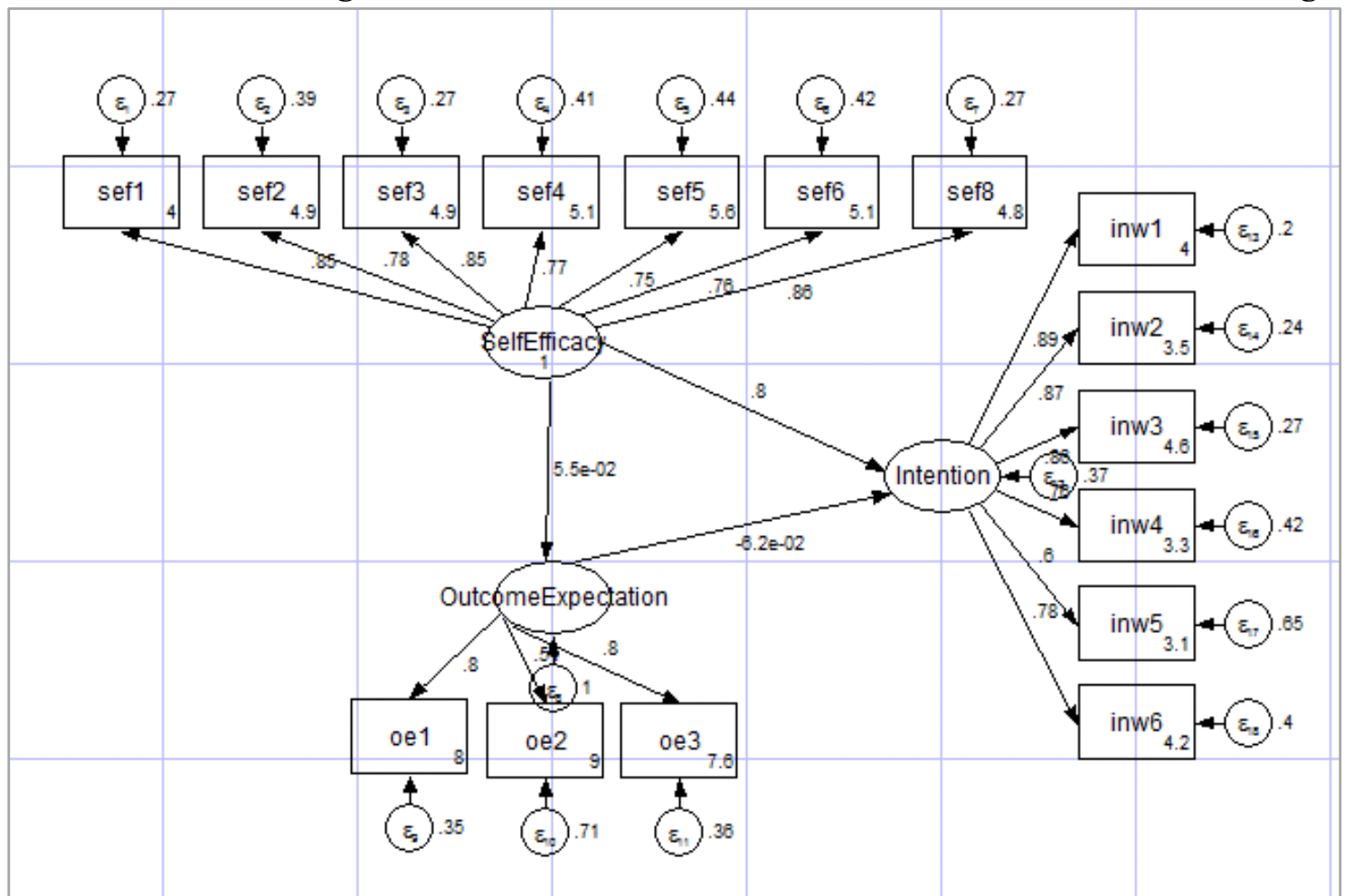

Sumber: Hasil olahan data primer, 2018

Gambar 3. Path Diagram dari Model Penelitian Setelah Mata Kuliah Auditing

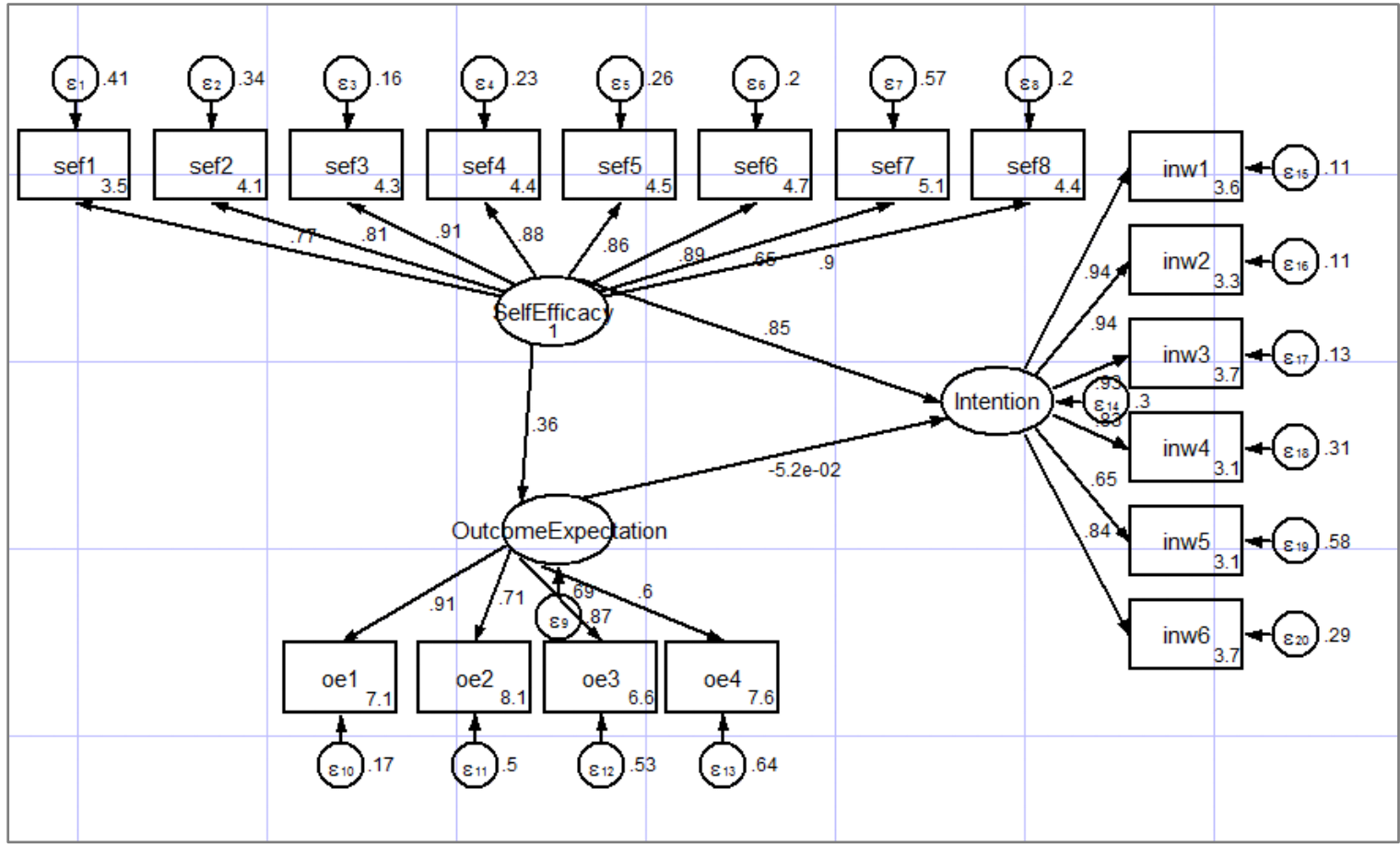

Sumber: Hasil olahan data primer, 2018

Hasil pengujian hipotesis secara ringkas dapat dilihat di Tabel 5. 
Tabel 5. Hasil Pengujian Model Struktural

\begin{tabular}{|c|c|c|c|c|c|c|c|}
\hline \multirow[b]{2}{*}{ Hipotesis } & \multirow[b]{2}{*}{ Hubungan antar Konstruk } & \multicolumn{3}{|c|}{ Sebelum Kuliah Audit } & \multicolumn{3}{|c|}{ Setelah Kuliah Audit } \\
\hline & & $\begin{array}{c}\text { Path } \\
\text { coefficients }\end{array}$ & p-value & Result & $\begin{array}{c}\text { Path } \\
\text { coefficients }\end{array}$ & $p$-value & Result \\
\hline $\mathrm{H}_{1}$ & Self-Efficacy $\rightarrow$ Intention & 0,79 & 0,000 & Accepted & 0,85 & 0,000 & Accepted \\
\hline $\mathrm{H}_{2}$ & $\begin{array}{l}\text { Outcome Expectation } \rightarrow \\
\text { Intention }\end{array}$ & $-0,06$ & 0,228 & Rejected & $-0,05$ & 0,281 & Rejected \\
\hline $\mathrm{H}_{3}$ & $\begin{array}{l}\text { Self-Efficacy } \rightarrow \text { Outcome } \\
\text { Expectation }\end{array}$ & 0,054 & 0,474 & Rejected & 0,362 & 0.000 & Accepted \\
\hline
\end{tabular}

Sumber: Hasil olahan data primer, 2018

Pada model sebelum kuliah auditing, hubungan antara self-efficacy dan intention adalah positif signifikan $(p<0,05)$ dengan kooefisien 0,79 . Begitu juga pada model setelah mata kuliah auditing, didapatkan hasil positif signifikan dengan nilai koefisien yang lebih besar dari model sebelumnya $(\beta=0,85, p<0,05)$. Jadi, hipotesis 1 diterima yang berarti bahwa hubungan antara self-efficacy dan niat mahasiswa untuk bekerja sebagai akuntan publik lebih kuat setelah mendapat mata kuliah auditing.

Hubungan antar outcome expectation dan intention tidak didukung baik pada model sebelum kuliah audit $(\beta=-0,06, p>0,1)$, maupun pada model setelah mata kuliah audit $(\beta=-0,05, p>0,1)$. Ini berarti bahwa hubungan antara harapan akan hasil jika mahasiswa menjadi akuntan publik dan niat mereka untuk bekerja sebagai akuntan publik tidak terbukti di kedua model.

Hasil pengujian antara selfefficacy dan outcome expectation pada model sebelum kuliah auditing terbukti tidak signifikan $(\beta=0,054, p>0,1)$, sedangkan pada model setelah kuliah auditing, hubungan antara self-efficacy dan outcome expectation terbukti positif signifikan dengan $p<0,05$ dan koefisien sebesar 0,379. Hal ini mengindikasikan bahwa setelah mendapat mata kuliah audit mahasiswa lebih cenderung memiliki ekspektasi tertentu akan hasil yang diraihnya karena perubahan self-efficacy.

\subsection{Pembahasan}

Penelitian ini mengaplikasikan model SCCT (Lent et al, 1994) untuk memprediksi niat mahasiswa untuk bekerja sebagai akuntan publik. Menurut model SCCT, selfefficacy berpengaruh positif terhadap niat seseorang untuk mencapai tujuan karirnya. Hasil dari penelitian ini menunjukkan bahwa hubungan antara selfeefficacy dan niat mahasiswa untuk bekerja sebagai akuntan publik positif signifikan, sejalan dengan penelitian Segal et al. (2002), Schoenfeld et al. (2017), Hayes \& Credle (2008), Lent et al (2001), dan hubungan ini semakin kuat setelah mengambil matakuliah auditing. Hal ini menunjukkan keefektifan matakuliah audit dalam meningkatkan hubungan antara self-efficacy dan niat mahasiswa untuk bekerja sebagai akuntan publik. Sesuai dengan yang dikemukakan oleh Wilson et al. (2007) dan Subramaniam \& Freudenberg (2007), pendidikan berpengaruh pada peningkatan self-efficacy. Perubahan pada self-efficacy yang kian meningkat setelah mengambil matakuliah auditing tentunya akan semakin memantapkan niat mahasiswa untuk bekerja sebagai akuntan publik. 
Hubungan antara outcome expectation dan niat mahasiswa bekerja sebagai akuntan publik ditemukan negatif tidak signifikan baik sebelum maupun sesudah mengambil matakuliah audit. Hal ini menunjukkan bahwa semakin penting hasil yang mereka ekspektasikan tidak mempengaruhi niat mereka untuk menjadi akuntan publik. Hasil ini bertentangan dengan temuan Schoenfeld et al., (2017), Diegelman \& Subich (2001), dan Lent et al. (2001). Hasil tidak signifikan ini sejalan dengan penelitian Lent et al. $(2003,2008)$ yang menemukan bahwa outcome expectation tidak berpengaruh pada interest maupun intention seseorang akan suatu tujuan karir. Secara singkat, dapat disimpulkan bahwa outcome expectation bukanlah faktor yang mempengaruhi niat mahasiswa untuk bekerja sebagai akuntan publik. Hasil yang mereka harapkan sebagai akuntan publik berupa materi maupun non materi terbukti tidak menjadi penentu pilihan karir mahasiswa.

Hubungan antara self-efficacy dan outcome expectation sebagai akuntan publik hanya terbukti pada pada model setelah mahasiswa mengambil matakuliah auditing. Ini menunjukkan bahwa kecenderungan mahasiswa atas ekspektasinya akan hasil yang akan diraihnya jika menjadi akuntan publik dapat berubah jika diintervensi melalui pendidikan yakni dalam matakuliah auditing. Seperti yang dikemukakan oleh Bandura (1986), salah satu penentu tinggi rendahnya self efficacy seseorang adalah social persuasion. Social persuation melalui mata kuliah auditing memberikan keyakinan kepada mahasiswa bahwa mereka memiliki kapabilitas untuk menjadi akuntan publik. Ketika terjadi perubahan pada self-efficacy berarti akan terjadi perubahan pada keyakinan dan kepercayaan diri mahasiswa, sehingga berpotensi untuk merubah outcome expectation mahasiswa akan apa yang mungkin ia dapatkan jika mewujudkan karir sebagai akuntan publik. Setelah mengambil matakuliah auditing tentunya mahasiswa sudah mempunyai gambaran tentang apa yang akan dikerjakan ketika jadi auditor. Sehingga, sesuai dengan model SCCT, ketika mahasiswa sudah mengetahui apa yang dilakukan sebagai seorang auditor di mata kuliah auditing, mahasiswa yang memiliki self efficacy tinggi akan memiliki ekspekstasi mengenai hasil yang akan diraihnya ketika berkarir menjadi auditor di kemudian hari.

\section{PENUTUP}

Tujuan dari penelitian ini adalah menguji hubungan antara self-efficacy, outcome expectation dan niat mahasiswa untuk bekerja sebagai akuntan publik menggunakan model social cognitive career theory yang dikembangkan oleh Lent et al. (1994). Hasil penelitian ini menunjukkan bahwa hubungan antara self-efficacy dan niat mahasiswa untuk menjadi akuntan publik lebih kuat setelah mengambil matakuliah auditing. Namun, hubungan antara outcome expectation dan niat untuk bekerja sebagai akuntan publik tidak signifikan baik sebelum dan sesudah matakuliah auditing. Begitu juga hubungan antara self-efficacy dan outcome expectation yang signifikan hanya pada setelah mengambil matakuliah auditing.

Penelitian ini memperkaya literatur dengan mendukung model SCCT secara parsial dan menunjukkan keefektifan matakuliah auditing karena memperkuat hubungan antara self-efficacy dan niat bekerja mahasiswa sebagai akuntan publik. Hasil 
penelitian ini memberikan wawasan kepada para penyedia pendidikan akuntansi di Indonesia untuk meningkatkan kualitas pengajaran matakuliah auditing dengan mendesain kurikulum yang dapat meningkatkan kompetensi dan kepercayaan diri mahasiswa di bidang audit. Praktikum dan magang di kantor akuntan publik bisa menjadi cara bagi mahasiswa untuk lebih meningkatkan kompetensinya. Bagi para pendidik, tentunya untuk lebih memfasilitasi dan melakukan persuasi verbal untuk lebih menguatkan ketertarikan dan komitmen mahasiswa untuk menjadi akuntan publik.

Penelitian ini mencatatkan beberapa keterbatasan yang mungkin dapat menjadi pembelajaran untuk penelitian selanjutnya. Pertama, pengambilan data penelitian ini diambil setelah mahasiswa menyelesaikan matakuliah Auditing 1. Pada beberapa universitas, terutama universitas yang menjadi responden dalam penelitian ini, matakuliah auditing dibagi menjadi Auditing 1 dan Auditing 2. Artinya untuk menguasai semua matakuliah auditing dibutuhkan paling tidak dua semester atau satu tahun. Karena keterbatasan waktu, pengambilan data hanya diambil pada sebelum dan sesudah mahasiswa mengambil matakuliah Auditing 1. Untuk penelitian selanjutnya, untuk mengetahui dampak matakuliah auditing pada self-efficacy, outcome expectation, dan niat mahasiswa untuk bekerja sebagai akuntan publik, sebaiknya pengambilan data dilakukan setelah matakuliah Auditing 2. Bisa saja temuan yang dihasilkan berbeda, karena setelah mengambil matakuliah Auditing 2 mahasiswa lebih menguasai sehingga lebih menguatkan self-efficacy mereka, atau malah melemahkan karena matakuliah Auditing 2 yang semakin sulit.

Kedua, responden penelitian ini berasal dari universitas ternama di kota besar. Faktor universitas ternama di kota besar bisa saja membentuk self-efficacy yang relatif sudah cukup baik dan ekspektasi mahasiswa akan hasil yang diinginkan dari profesi akuntan publik sudah cukup memadai karena beberapa universitas tersebut sudah bekerjasama dengan beberapa KAP ternama. Penelitian selanjutnya sebaiknya memperluas cakupan responden dari berbagai jenis universitas dan daerah. Karena latar belakang universitas dan daerah yang berbeda-beda bisa saja mempengaruhi selfefficacy mahasiswa secara khusus dan hasil penelitian secara umum.

Ketiga, penelitian ini tidak menganalisis faktor gender, suku, latar belakang budaya dan nilai akademis yang bisa saja menjadi sumber yang dapat mempengaruhi keyakinan individu akan kompentensinya (Flores, Navarro, \& DeWitz, 2008; Ismail et al., 2017). Penelitian selanjutnya dapat menguji model SCCT ini berdasarkan gender, suku, latar belakang budaya dan nilai akademis mahasiswa.

Keempat, penelitian ini tidak menguji pengaruh tidak langsung (indirect effect) antara self-efficacy dan niat untuk bekerja sebagai akuntan publik melalui outcome expectation, karena seperti yang sudah dijelaskan sebelumnya, hubungan antara selfefficacy dan outcome expectation tidak signifikan pada sebelum mengambil matakuliah audit. Penelitian selanjutnya sebaiknya menguji variabel lain yang mungkin memediasi hubungan antara self-efficacy dan niat untuk menjadi akuntan publik. 


\section{DAFTAR PUSTAKA}

Ahmad, Z., Ismail, H., \& Anantharaman, R. N. (2015). To be or not to be: an investigation of accounting students' career intentions. Education + Training, 57(3), 360-376. https://doi.org/10.1108/ET-03-2014-0025

Anderson, S. L., \& Betz, N. E. (2001). Sources of Social Self-Efficacy Expectations: Their Measurement and Relation to Career Development. Journal of Vocational Behavior, 58(1), 98-117. https://doi.org/10.1006/jvbe.2000.1753

Bandura, A. (1986). Social foundations of thought and action: A social cognitive theory. Prentice-Hall, Inc. Retrieved from http://psycnet.apa.org/psycinfo/1985-98423000/

Bandura, A. (1992). Exercise of personal agency through the self-efficacy mechanism. In Self-efficacy: Thought control of action (pp. 3-38). Washington, DC, US: Hemisphere Publishing Corp.

Bandura, A., \& Adams, N. E. (1977). Analysis of self-efficacy theory of behavioral change. Cognitive Therapy and Research, 1(4), 287-310.

Bandura, A., \& Wood, R. (1989). Effect of perceived controllability and performance standards on self-regulation of complex decision making. Journal of Personality and Social Psychology, 56(5), 805.

Bremser, W. G., Brenner, V. C., \& Dascher, P. E. (1977). The feasibility of professional schools: An empirical study. Accounting Review, 465-473.

Cunningham, G. B., Bruening, J., Sartore, M. L., Sagas, M., \& Fink, J. S. (2005). The Application of Social Cognitive Career Theory to Sport and Leisure Career Choices. Journal of Career Development, 32(2), 122-138. https://doi.org/10.1177/0894845305279164

DeZoort, F. T., Lord, A. T., \& Cargile, B. R. (1997). A comparison of accounting professors' and students' perceptions of the public accounting work environment. Issues in Accounting Education, 12(2), 281.

Diegelman, N. M., \& Subich, L. M. (2001). Academic and Vocational Interests as a Function of Outcome Expectancies in Social Cognitive Career Theory. Journal of Vocational Behavior, 59(3), 394-405. https://doi.org/10.1006/jvbe.2001.1802

Erkut, S., \& Mokros, J. R. (1984). Professors as Models and Mentors for College Students. American Educational Research Journal, 21(2), 399-417. https://doi.org/10.3102/00028312021002399

Flores, L. Y., Navarro, R. L., \& DeWitz, S. J. (2008). Mexican American High School Students' Postsecondary Educational Goals: Applying Social Cognitive Career Theory. Journal of Career Assessment, 16(4), 489-501. https://doi.org/10.1177/1069072708318905

Ghani, E. K., Said, J., \& Nasir, N. M. (2008). Determinants of Malaysian adult learners' distance learning. Distance Learning, 10.

Hackett, G., \& Betz, N. E. (1981). A self-efficacy approach to the career development of women. Journal of Vocational Behavior, 18(3), 326-339. https://doi.org/10.1016/0001-8791(81)90019-1 
Hayes, Z. A., \& Credle, S. H. (2008). An application of social cognitive career theory: exploring factors influencing the decision to select public accounting as a career choice. Retrieved April 11, 2017, from http://www.freepatentsonline.com/article/International-Journal-BusinessResearch/190617011.html

Henseler, J., Ringle, C. M., \& Sinkovics, R. R. (2009). The use of partial least squares path modeling in international marketing. In New challenges to international marketing (pp. 277-319). Emerald Group Publishing Limited.

Hulland, J. (1999). Use of partial least squares (PLS) in strategic management research: A review of four recent studies. Strategic Management Journal, 195-204.

Iskandar, T. M., \& Sanusi, Z. M. (2011). Assessing the Effects of Self-Efficacy and Task Complexity on Internal Control Audit Judgment. Asian Academy of Management Journal of Accounting and Finance, 7(1), 29-52.

Ismail, M., Aziz, F. H., AB, M. F., Ismail, M. F., \& PM, A. S. (2017). Social foundations of thought and action: A social cognitive theory. International Journal of Applied Psychology, 7(2), 44-47.

James, K. L., \& Hill, C. (2009). Race and the development of career interest in accounting. Journal of Accounting Education, 27(4), 210-222. https://doi.org/10.1016/j.jaccedu.2010.07.005

Lent, R. W., Brown, S. D., Brenner, B., Chopra, S. B., Davis, T., Talleyrand, R., \& Suthakaran, V. (2001). The role of contextual supports and barriers in the choice of math/science educational options: A test of social cognitive hypotheses. Journal of Counseling Psychology, 48(4), 474-483. https://doi.org/10.1037//00220167.48.4.474

Lent, R. W., Brown, S. D., \& Hackett, G. (1994). Toward a unifying social cognitive theory of career and academic interest, choice, and performance. Journal of Vocational Behavior, 45(1), 79-122.

Lent, R. W., Brown, S. D., Schmidt, J., Brenner, B., Lyons, H., \& Treistman, D. (2003). Relation of contextual supports and barriers to choice behavior in engineering majors: Test of alternative social cognitive models. Journal of Counseling Psychology, 50(4), 458-465. https://doi.org/10.1037/0022-0167.50.4.458

Lent, R. W., Ezeofor, I., Morrison, M. A., Penn, L. T., \& Ireland, G. W. (2016). Applying the social cognitive model of career self-management to career exploration and decision-making. Journal of Vocational Behavior, 93, 47-57. https://doi.org/10.1016/j.jvb.2015.12.007

Lent, R. W., Ireland, G. W., Penn, L. T., Morris, T. R., \& Sappington, R. (2017). Sources of self-efficacy and outcome expectations for career exploration and decision-making: A test of the social cognitive model of career self-management. Journal of Vocational Behavior, 99, 107-117. https://doi.org/10.1016/j.jvb.2017.01.002

Navarro, R. L., Flores, L. Y., \& Worthington, R. L. (2007). Mexican American middle school students' goal intentions in mathematics and science: A test of social 
cognitive career theory. Journal of Counseling Psychology, 54(3), 320-335. https://doi.org/10.1037/0022-0167.54.3.320

Pihie, Z. A. L. (2009). Entrepreneurship as a career choice: An analysis of entrepreneurial self-efficacy and intention of university students. European Journal of Social Sciences, 9(2), 338-349.

Pratama, A. (2017). Why Do Accounting Students Choose a Career in Accountancy? An Exploratory Study in Bandung City, West Java, Indonesia, 6(2), 15.

Schoenfeld, J., Segal, G., \& Borgia, D. (2017). Social cognitive career theory and the goal of becoming a certified public accountant. Accounting Education, 26(2), 109126. https://doi.org/10.1080/09639284.2016.1274909

Schunk, D. H. (1985). Self-efficacy and classroom learning. Psychology in the Schools, 22(2), 208-223.

Segal, G., Borgia, D., \& Schoenfeld, J. (2002). Using Social Cognitive Career Theory to Predict Self-Employment Goals. New England Journal of Entrepreneurship, 5(2), 47-56. https://doi.org/10.1108/NEJE-05-02-2002-B007

Silvia, P. J. (2003). Self-efficacy and interest: Experimental studies of optimal incompetence. Journal of Vocational Behavior, 62(2), 237-249. https://doi.org/10.1016/S0001-8791(02)00013-1

Subramaniam, N., \& Freudenberg, B. (2007). Preparing accounting students for success in the professional environment: Enhancing self-efficacy through a work integrated learning programme. Retrieved from https://papers.ssrn.com/sol3/papers.cfm?abstract_id=1493467

Wilson, F., Kickul, J., \& Marlino, D. (2007). Gender, entrepreneurial self-efficacy, and entrepreneurial career intentions: implications for entrepreneurship education. Entrepreneurship Theory and Practice, 31(3), 387-406.

Yuliansyah, \& Suryani, A. (2015, March). Tantangan Pengembangan profesi Akuntan Publik di Daerah. Retrieved May 1, 2018, from http://iaiglobal.or.id/v03/majalah-akuntan/files/Februari-Maret2016 